\title{
Reduction of benzylic alcohols and $\alpha$-hydroxy- carbonyl compounds by hydriodic acid in a biphasic reaction medium
}

\author{
Michael Dobmeier ${ }^{1}$, Josef M. Herrmann ${ }^{1}$, Dieter Lenoir ${ }^{2}$ \\ and Burkhard König*1
}

\author{
Full Research Paper \\ Address: \\ ${ }^{1}$ Institute of Organic Chemistry, University of Regensburg, D-93040 \\ Regensburg, Germany, Fax: +499419431717 and ${ }^{2}$ Helmholtz \\ Zentrum München, Ingolstädter Landstraße 1, D-85764 Neuherberg, \\ Germany \\ Email: \\ Burkhard König* - Burkhard.Koenig@chemie.uni-regensburg.de \\ * Corresponding author \\ Keywords: \\ alcohols; catalysis; iodine; phosphorous reduction
}

\author{
Beilstein J. Org. Chem. 2012, 8, 330-336. \\ doi:10.3762/bjoc. 8.36 \\ Received: 29 December 2011 \\ Accepted: 16 February 2012 \\ Published: 02 March 2012 \\ Associate Editor: D. Y.-K. Chen \\ () 2012 Dobmeier et al; licensee Beilstein-Institut. \\ License and terms: see end of document.
}

\begin{abstract}
The synthetic protocol for the reduction of alcohols to hydrocarbons by using hydriodic acid, first described by Kiliani more than 140 years ago, was improved to be more applicable to organic synthesis. Instead of a strongly acidic, aqueous solution, a biphasic toluene-water reaction medium was used, which allowed the conversion of primary, secondary and tertiary benzylic alcohols, in good yields and short reaction times, into the corresponding hydrocarbons. Red phosphorous was used as the stoichiometric reducing agent. Keto, ester, amide or ether groups are tolerated, and catalytic amounts of hydriodic acid ( 0.2 equiv) in the presence of 0.6 equiv phosphorous are sufficient to achieve conversion.
\end{abstract}

\section{Introduction}

The reduction of hydroxy groups is a typical and important step in the synthesis of complex natural products or drugs [1-4]. Functional-group tolerance during this reduction step is essential since various other groups are usually present. A number of synthetic procedures have been developed, which allow selective reduction, but only a few one-step transformations are known, which use either titanium(III) [5-8] or different metal complexes [9-13]. Most procedures require a sequence of steps, e.g., the conversion of hydroxy groups into a chloride or bro- mide substituent and subsequent catalytic reduction with $\mathrm{H}_{2} / \mathrm{Pt}$ or the conversion into a tosylate and reduction with $\mathrm{LiAlH}_{4}$. The most commonly applied method is the Barton-McCombie reaction [14], due to its versatility and its very high functionalgroup tolerance [15-18]. Although very general, the reaction has some drawbacks: The involved organotin hydrides are costly, highly toxic [19-21] and often difficult to separate from the reaction products. Furthermore, secondary alcohols give best results, while others may react less efficiently. 
We have reinvestigated the long-known reduction of benzylic alcohols and $\alpha$-hydroxycarbonyl compounds by hydriodic acid [22-32]. The method has been reported for a variety of alcohols, but typically proceeds in aqueous solution and requires an excess of HI or strong mineral acids such as phosphoric or sulfuric acid [33-35]. We describe a biphasic reaction medium consisting of toluene and aqueous hydriodic acid. The phase separation allows milder reaction conditions compared to the classic Kiliani protocol and is more applicable to organic synthesis.

\section{Results and Discussion}

Initial investigations focused on simple benzylic alcohols (Table 1, entries 1-3), which were converted in high to quantitative yields into the corresponding alkanes. Carbonyl groups or amides in a benzylic position (Table 1, entries 4 and 6) and aromatic hydroxy groups (Table 2 , entry 7 ) or aromatic ethers (Table 1, entry 5) were not affected. Moreover, heterocycles such as thiophene (Table 1, entry 7) were stable under these conditions whereas furans (Table 1, entry 8 ) were decomposed due to ring opening. Benzylic alcohols were converted in good

Table 1: Reduction of benzylic alcohols to the corresponding alkanes.

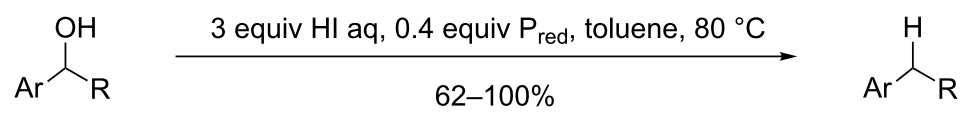

\begin{tabular}{|c|c|c|c|c|}
\hline Entry & Alcohol & Product $^{a}$ & Time [h] & Yield [\%] \\
\hline 1 & & & 2 & $70^{\mathrm{b}}$ \\
\hline 2 & & & 0.5 & 96 \\
\hline 3 & & & 0.25 & 100 \\
\hline 4 & & & 1 & 80 \\
\hline 5 & & & 0.5 & 92 \\
\hline 6 & & & 1 & 82 \\
\hline 7 & & & 0.5 & $62^{c}$ \\
\hline 8 & & compositi & 1 & - \\
\hline 9 & & & 0.25 & $74^{\mathrm{C}}$ \\
\hline
\end{tabular}


Table 1: Reduction of benzylic alcohols to the corresponding alkanes. (continued)

10<smiles>CC(C)CC(O)c1ccccc1</smiles>

11

12<smiles>OC(c1ccccc1)C(O)c1ccccc1</smiles><smiles>CCOC(=O)C(O)C(O)C(=O)OCC</smiles><smiles>CC(C)CCc1ccccc1</smiles><smiles>CCOC(=O)CCC(=O)OCC</smiles>

0.5

1.5 $49^{c}$

aAll products are known compounds described in the literature. The identities have been proven by proton NMR and mass analysis, which match the literature data. ${ }^{\mathrm{b}}$ The corresponding iodo compound was identified as a byproduct. ${ }^{\mathrm{C}}$ The corresponding elimination product was obtained as a byproduct.

to high yields to alkanes with increasing reactivity in the order primary $(2 \mathrm{~h})<\operatorname{secondary}(0.5-1 \mathrm{~h})<$ tertiary alcohol $(15-30$ min); carbonyl groups and ethers were tolerated. Diethyl tartrate was converted into diethyl succinate under the reaction conditions given (Table 1, entry 12), but some of the material was lost due to ester hydrolysis.

Allylic alcohols are completely consumed, but the corresponding alkenes could not be isolated as pure products (Table 2). Mixtures of eliminiation and deoxygenation products, in some cases also rearangement of the deoxygenated product into the the more highly substitued, thermodynamically more stable alkene occurred. Propargylic alcohols (Table 2, entry 3 and 4) showed elimination or decomposed. In the case of flavin (Table 2, entry 6), three hydroxy groups were reduced and one was converted into an iodo substituent.

Alcohols other than those that were benzylic or $\alpha$ to carbonyl groups were not converted into the corresponding alkanes, and the reaction stopped at the iodoalkanes (Table 3 ). The reactivity follows the order of primary $<$ secondary $<$ tertiary alcohols, as expected for an $\mathrm{S}_{\mathrm{N}} 1$ reaction. The reduction potential of the nonbenzylic iodoalkanes is not sufficient for reduction by hydriodic acid.

Table 2: Alcohols showing incomplete or unselective reaction with hydriodic acid and red phosphorous ( 3.0 equiv $\mathrm{HI}, 0.4$ equiv $\left.\mathrm{P}_{\text {red }}\right)$

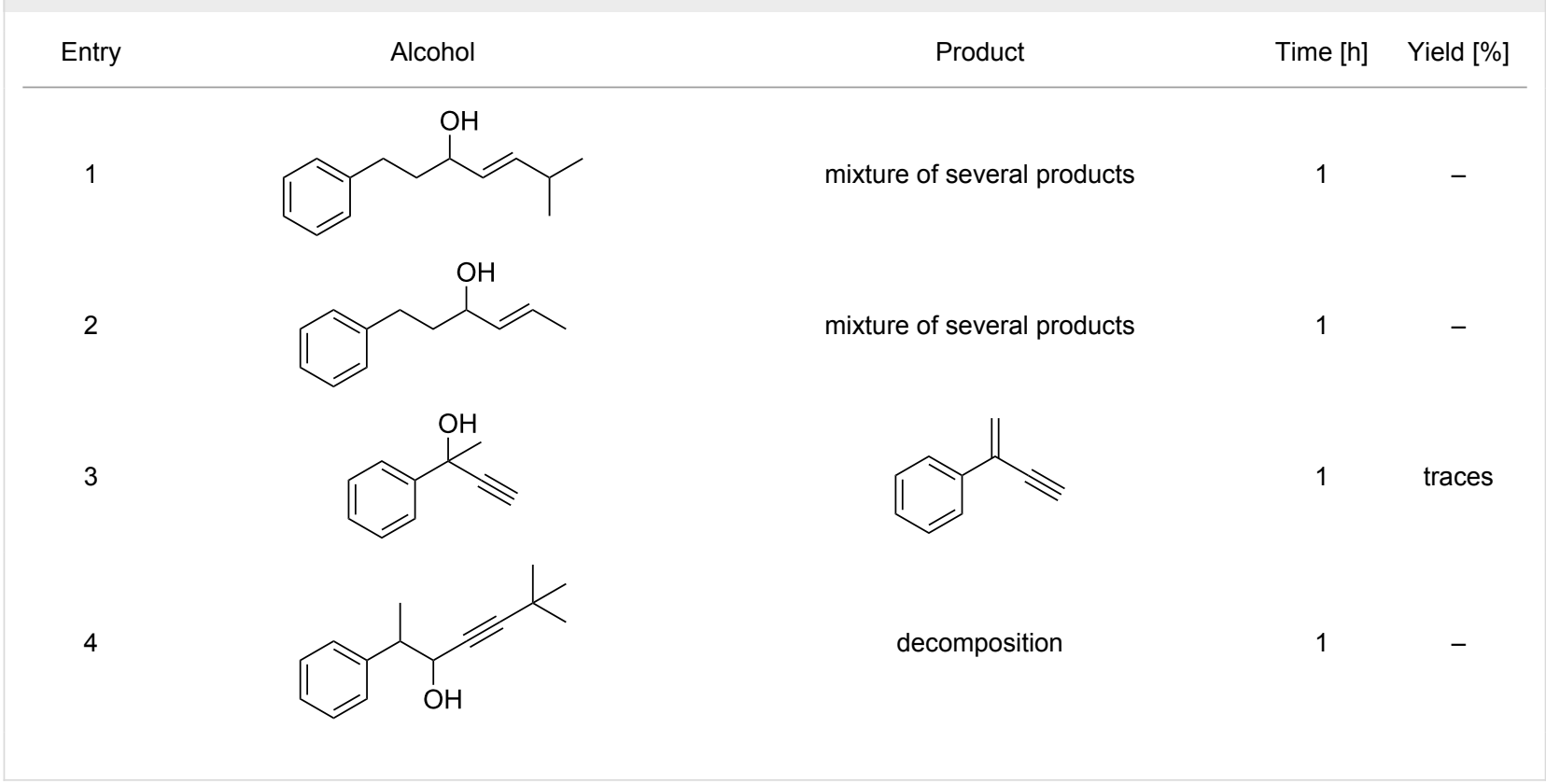


Table 2: Alcohols showing incomplete or unselective reaction with hydriodic acid and red phosphorous (3.0 equiv $\mathrm{HI}, 0.4$ equiv $\left.\mathrm{P}_{\text {red }}\right)$. (continued)

5<smiles>O=C1C=CC(O)C1</smiles>

6<smiles>Cc1cc2nc3c(=O)[nH]c(=O)nc-3n(CC(O)C(O)CO)c2cc1C</smiles>

7 decomposition<smiles>Cc1cc2nc3c(=O)[nH]c(=O)nc-3n(CCCCCI)c2cc1C</smiles>

no conversion
2
Table 3: Alcohols yielding alkyl iodides with hydriodic acid and red phosphorous. $^{a}$

Entry Alcohol Product $\begin{gathered}\text { Time [h] Yield [\%] } \\ 3\end{gathered}$

a3 equiv $\mathrm{HI}, 0.4$ equiv $\mathrm{P}_{\text {red. }}{ }^{\text {bSingle isomer. }}{ }^{\mathrm{c} P r o d u c t s}$ were analyzed by gas chromatography; chlorobenzene was used as an internal standard.

The mechanism of reduction by hydriodic acid consists of two steps (Scheme 1): The nucleophilic substitution of the hydroxy group by iodide and the subsequent reduction of the alkyl iodide by hydriodic acid. The mechanistic details of the redox comproportionation of alkyl iodides and $\mathrm{H}-\mathrm{I}$ have been strongly debated in the literature [36-38]. However, the required benzylic or $\alpha$-carbonyl position for the redox comproportionation indicates an intermediate with mesomeric stabilization due to the adjacent $\pi$-system. In a trapping experiment, using HI without phosphorous, diphenylcarbinol as the substrate and TEMPO as a trapping agent for radical intermediates, the TEMPO adduct of diphenylcarbinol was detected by mass analysis. This indicates a radical mechanism of the redox

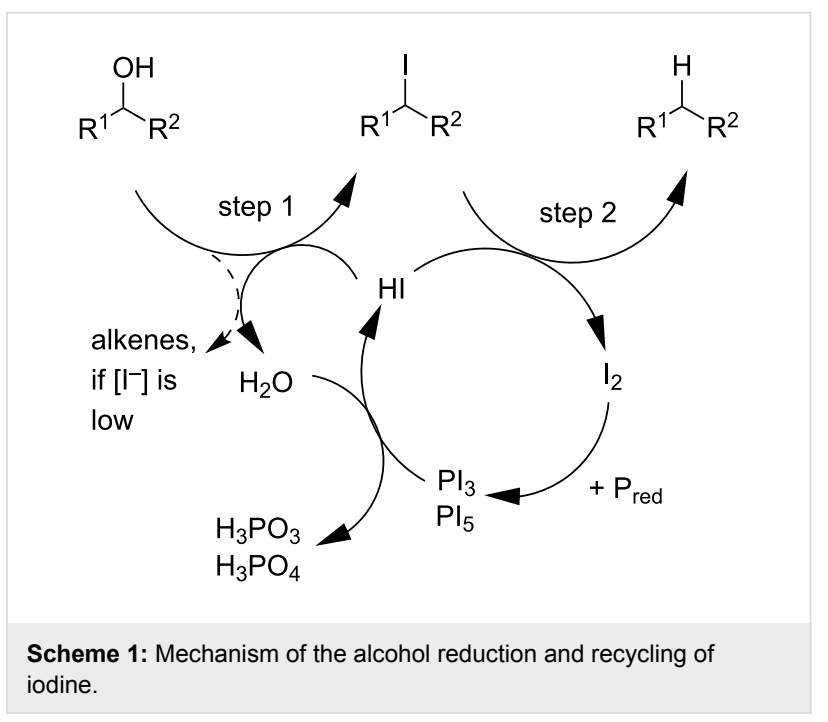

comproportionation. We suggest a stepwise reduction by single electron transfer (SET) accompanied by the oxidation of $\mathrm{I}^{-}$to $\mathrm{I}_{2}$. The iodine, generated in the second step, is recycled by reduction with red phosphorous, regenerating hydriodic acid. Admittedly, the above-mentioned TEMPO adduct could also be generated by nucleophilic substitution of the alkyl iodide with reduced TEMPO. At least this would be another proof for the first reaction step. According to the redox equations of the reaction between iodine and red phosphorous, each mole of red phosphorous is able to reduce at least $1.5 \mathrm{~mol}$ of iodine. Catalytic amounts of hydriodic acid are therefore sufficient [28] for the reduction of the hydroxy group (Table 4), when excess red phosphorous is added as a terminal reducing agent. However, depending on the amount of added hydriodic acid, the 


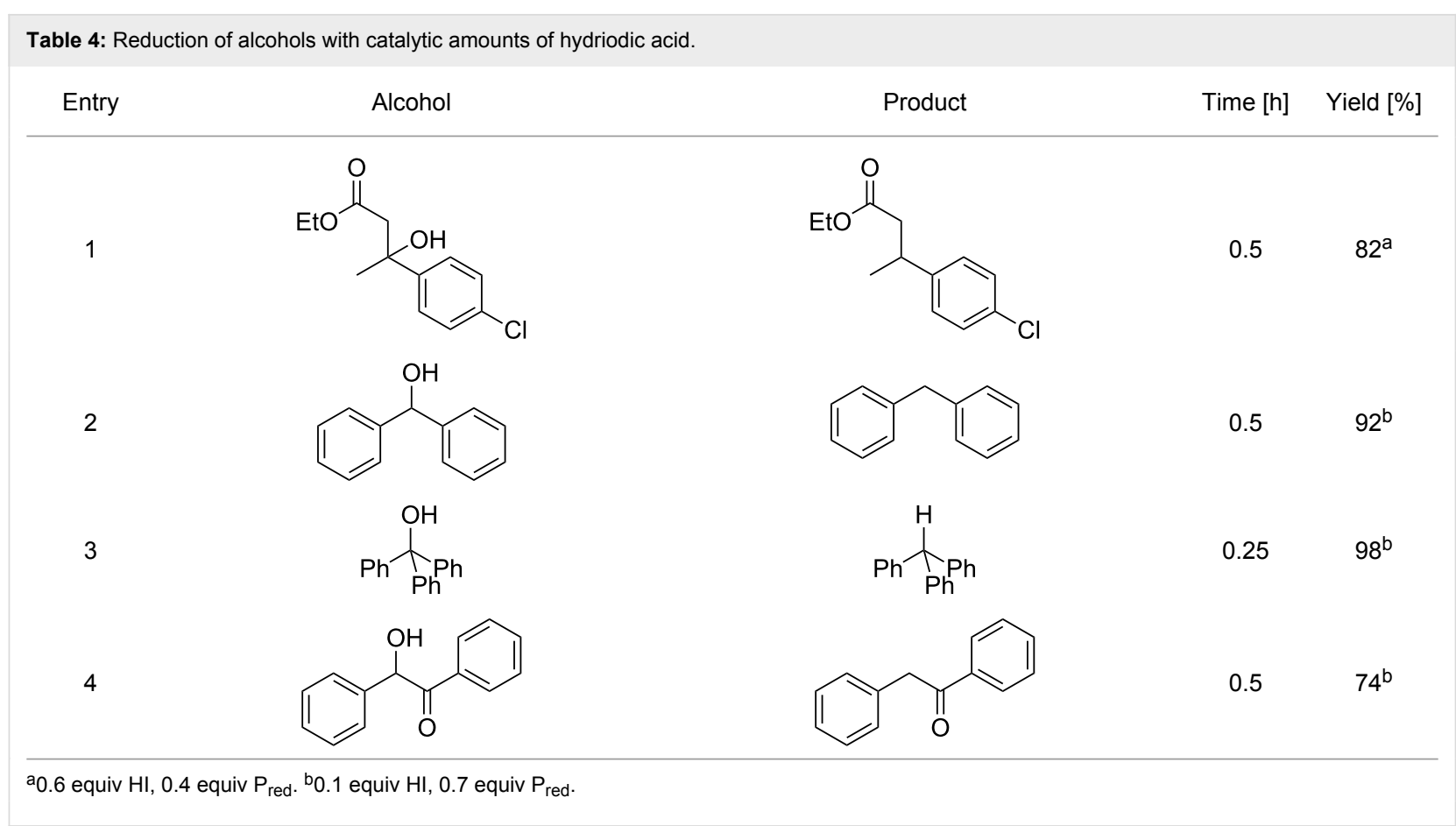

elimination of water may occur as an alternative reaction pathway. A low concentration of $\mathrm{HI}$ favors the elimination of water, while higher HI concentrations lead to substitution and reduction products.

\section{Conclusion}

Toluene and aqueous hydriodic acid are a suitable biphasic reaction mixture for the reduction of a range of benzylic alcohols. The two-phase system makes the Kiliani protocol more easily applicable to organic synthesis, as organic substrates and products dissolve in the organic phase and are separated from the mineral acids. The procedure allows the use of catalytic amounts of hydriodic acid and red phosphorous as the terminal reductant. In the case of alcohols having no activation by adjacent benzylic or carbonyl groups the reaction stops at the corresponding alkyl iodide. A quantitative mass-efficiency analysis [39] of the reaction in comparison to tosylation/LAH, Ti(III)-mediated and Barton-McCombie reduction revealed a better atom economy and mass efficiency.

\section{Experimental}

Representative experimental procedure: The alcohol ( $1 \mathrm{mmol}, 1$ equiv) is dissolved in $4 \mathrm{~mL}$ of toluene. Red phosphorus $(0.4 \mathrm{mmol})$, followed by concentrated hydriodic acid $(57 \% \mathrm{w} / \mathrm{w} ; 3.0 \mathrm{mmol}, 3$ equiv) is added and the reaction mixture is heated to $80{ }^{\circ} \mathrm{C}$ for the stated time, allowed to cool to rt and quenched with $\mathrm{Na}_{2} \mathrm{~S}_{2} \mathrm{O}_{3}(10 \mathrm{~mL} ; 10 \% \mathrm{w} / \mathrm{w})$ solution. The aqueous phase is extracted with dichloromethane $(3 \times 10 \mathrm{~mL})$, the combined organic phases are dried over
$\mathrm{MgSO}_{4}$ and filtered, and the solvent is removed. The crude product is purified by chromatography and spectroscopically characterized.

For catalytic reactions of $1 \mathrm{mmol}$ of the respective alcohol the following amounts of hydriodic acid and $\mathrm{P}_{\text {red }}$ were used: (a) $0.6 \mathrm{mmol} \mathrm{HI} / 0.4 \mathrm{mmol} \mathrm{P}_{\text {red }}$, (b) $0.1 \mathrm{mmol} \mathrm{HI} / 0.7 \mathrm{mmol} \mathrm{P}_{\text {red }}$.

(E)-6-Methyl-1-phenylhept-4-en-3-ol (Table 2, entry 1): The reaction was carried out under dry nitrogen atmosphere by using standard Schlenk techniques. To a slurry of $\mathrm{Mg}$ powder $(0.67 \mathrm{~g}, 28 \mathrm{mmol})$ in dry THF $(4 \mathrm{~mL}), 2 \mathrm{~mL}$ of a solution of 2-phenyl-1-bromethane $(3.0 \mathrm{~mL}, 28 \mathrm{mmol})$ in dry THF $(10 \mathrm{~mL})$ was added. The Grignard reaction was initiated by the addition of iodine followed by sonication for several minutes. When the exothermic reaction started the rest of the 2-phenyl-1bromethane solution was added through a septum by syringe over $15 \mathrm{~min}$. After the addition, the reaction solution was heated under reflux for $1 \mathrm{~h}$ to complete the reaction. The reaction solution was allowed to cool to rt before 4-methyl-2-pentenal $(2.3 \mathrm{~mL}, 20 \mathrm{mmol})$ was added dropwise. To complete the reaction the solution was again heated under reflux for $1 \mathrm{~h}$. The reaction was quenched by the addition of $\mathrm{HCl}(2 \mathrm{M}, 25 \mathrm{~mL})$. The aqueous phase was extracted with diethyl ether $(3 \times$ $15 \mathrm{~mL})$. The combined organic phases were washed with saturated $\mathrm{NaHCO}_{3}(15 \mathrm{~mL})$ and $\mathrm{H}_{2} \mathrm{O}(2 \times 10 \mathrm{~mL})$, and dried with $\mathrm{MgSO}_{4}$. The solvent was removed with a rotary evaporator. The crude product was purified by flash chromatography (petroleum ether/ethyl acetate $4: 1, R_{\mathrm{f}} 0.32$; staining with vanillin solu- 
tion gave a blue spot). (E)-6-Methyl-1-phenylhept-4-en-3-ol was isolated as a yellow oil in 74\% yield $(3.05 \mathrm{~g}, 14.9 \mathrm{mmol})$. ${ }^{1} \mathrm{H}$ NMR $\left(300 \mathrm{MHz}, \mathrm{CDCl}_{3}\right) \delta 7.33-7.14(\mathrm{~m}, 5 \mathrm{H}), 5.63$ (ddd, $J$ $=15.5,6.4,0.7 \mathrm{~Hz}, 1 \mathrm{H}), 5.44(\mathrm{ddd}, J=15.5,7.0,1.2 \mathrm{~Hz}, 1 \mathrm{H})$, 4.13-4.01 (m, 1H), 2.79-2.59 (m, 2H), 2.39-2.21 (m, 1H), $1.97-1.72(\mathrm{~m}, 2 \mathrm{H}), 1.58(\mathrm{~d}, J=2.7 \mathrm{~Hz}, 0.3 \mathrm{H}), 1.46(\mathrm{~d}, J=1.8$ $\mathrm{Hz}, 1 \mathrm{H}), 1.00$ (d, $J=6.8 \mathrm{~Hz}, 6 \mathrm{H}) ;{ }^{13} \mathrm{C} \mathrm{NMR}\left(75 \mathrm{MHz}, \mathrm{CDCl}_{3}\right)$ $\delta$ 139.6, 129.7, 128.5, 128.4, 125.8, 72.6, 38.8, 31.8, 30.7, 22.4, 21.3; EIMS m/z (\%): 91.1 (100) $\left[\mathrm{C}_{7} \mathrm{H}_{7}\right]^{+}, 161.1(81)[\mathrm{M}-$ $\left.\mathrm{C}_{3} \mathrm{H}_{7}\right]^{+}, 186.1(5)\left[\mathrm{M}-\mathrm{H}_{2} \mathrm{O}\right]^{+}, 204.2[\mathrm{M}]^{+} ; \operatorname{HRMS}(\mathrm{m} / \mathrm{z}):[\mathrm{M}]^{+}$ calcd for $\mathrm{C}_{14} \mathrm{H}_{20} \mathrm{O}$, 204.1514; found, 204.1511.

(E)-1-Phenylhex-4-en-3-ol (Table 2, entry 2): The reaction was carried out under a dry nitrogen atmosphere by using standard Schlenk techniques. A solution $(1 \mathrm{~mL})$ of 2-phenyl-1bromethane $(1.35 \mathrm{~mL}, 10.0 \mathrm{mmol})$ in dry THF $(10 \mathrm{~mL})$ was added to $\mathrm{Mg}$ powder $(0.25 \mathrm{~g}, 10 \mathrm{mmol})$. The Grignard reaction was initiated by the addition of iodine followed by sonication for several min. When the exothermic reaction started the rest of the 2-phenyl-1-bromethane solution was added through a septum by syringe over $15 \mathrm{~min}$. After the addition, the reaction solution was heated under reflux for $1 \mathrm{~h}$ to complete the reaction. The reaction solution was allowed to cool to $\mathrm{rt}$ before crotonaldehyde $(0.74 \mathrm{~mL}, 9.0 \mathrm{mmol})$ was added dropwise. To complete the reaction the solution was again heated under reflux for $2.5 \mathrm{~h}$. The reaction was quenched by the addition of $\mathrm{HCl}(2 \mathrm{M}, 10 \mathrm{~mL})$. The aqueous phase was extracted with diethyl ether $(2 \times 15 \mathrm{~mL})$. The combined organic phases were washed with saturated $\mathrm{NaHCO}_{3}(5 \mathrm{~mL}), \mathrm{H}_{2} \mathrm{O}(2 \times 5 \mathrm{~mL})$ and dried with $\mathrm{MgSO}_{4}$. The solvent was removed with a rotary evaporator. (E)-1-Phenylhex-4-en-3-ol was obtained in 96\% yield $(1.53 \mathrm{~g}, 8.69 \mathrm{mmol})$ in analytical purity. Analytical data were identical with the literature [40]. ${ }^{1} \mathrm{H}$ NMR $(300 \mathrm{MHz}$, $\left.\mathrm{CDCl}_{3}\right) \delta 7.34-7.06(\mathrm{~m}, 5 \mathrm{H}), 5.63(\mathrm{dq}, J=15.3,6.2 \mathrm{~Hz}, 1 \mathrm{H})$, $5.48(\mathrm{ddd}, J=15.3,7.0,1.4 \mathrm{~Hz}, 1 \mathrm{H}), 4.02(\mathrm{q}, J=6.7 \mathrm{~Hz}, 1 \mathrm{H})$, $2.73-2.56(\mathrm{~m}, 2 \mathrm{H}), 1.67(\mathrm{dd}, J=6.3,0.7 \mathrm{~Hz}, 3 \mathrm{H}), 1.52$ (s, $0.3 \mathrm{H}), 1.40(\mathrm{~s}, 0.7 \mathrm{H})$; EIMS $m / z(\%): 71.1(100)\left[\mathrm{C}_{4} \mathrm{H}_{7} \mathrm{O}\right]^{+}$, $91.1(67)\left[\mathrm{C}_{7} \mathrm{H}_{7}\right]^{+}, 105.1$ (19) $\left[\mathrm{M}-\mathrm{C}_{4} \mathrm{H}_{7} \mathrm{O}\right]^{+}, 176.1$ (50) $[\mathrm{M}]^{+}$.

1-(4-Methoxyphenyl)-2-phenylpropan-1-ol (Table 1, entry 5): The reaction was carried out under a dry nitrogen atmosphere by using standard Schlenk techniques. $1 \mathrm{~mL}$ of a solution of 4-bromo-1-methoxybenzene $(0.62 \mathrm{~mL}, 5.0 \mathrm{mmol})$ in dry THF $(10 \mathrm{~mL})$ was added to $\mathrm{Mg}$ powder $(0.12 \mathrm{~g}, 5.0 \mathrm{mmol})$. The Grignard reaction was initiated by the addition of iodine followed by sonication for several min. When the exothermic reaction started the rest of the 4-bromo-1-methoxybenzene solution was added through a septum by syringe over $15 \mathrm{~min}$. After the addition, the reaction solution was heated under reflux for $1 \mathrm{~h}$ to complete the reaction. The reaction solution was allowed to cool to rt before 2-phenylpropionaldehyde $(0.60 \mathrm{~mL}, 4.5 \mathrm{mmol})$ was added dropwise. To complete the reaction the solution was again heated under reflux for $2 \mathrm{~h}$. The reaction was quenched by the addition of $\mathrm{HCl}(2 \mathrm{M}, 5 \mathrm{~mL})$. The aqueous phase was extracted with diethyl ether $(2 \times 5 \mathrm{~mL})$. The combined organic phases were washed with saturated $\mathrm{NaHCO}_{3}(3 \mathrm{~mL}), \mathrm{H}_{2} \mathrm{O}(2 \times$ $2.5 \mathrm{~mL}$ ) and dried with $\mathrm{MgSO}_{4}$. The solvent was removed with a rotary evaporator. The crude product was purified by flash chromatography (petroleum ether/ethyl acetate $4: 1, R_{\mathrm{f}} 0.3$; staining with vanillin solution gave a blue spot). 1-(4Methoxyphenyl)-2-phenylpropan-1-ol was isolated as a yellow oil in 57\% yield $(0.62 \mathrm{~g}, 2.6 \mathrm{mmol})$. Analytical data are identical with literature [41]. ${ }^{1} \mathrm{H}$ NMR $\left(300 \mathrm{MHz}, \mathrm{CDCl}_{3}\right) \delta$ 7.45-7.05 (m, 7H), 6.85-6.74 (m, 2H), $4.76(\mathrm{~d}, J=6.1 \mathrm{~Hz}, 1 \mathrm{H})$, $3.78(\mathrm{~s}, 3 \mathrm{H}), 3.09$ (p, $J=6.9 \mathrm{~Hz}, 1 \mathrm{H}), 1.34(\mathrm{~d}, J=7.0 \mathrm{~Hz}, 3 \mathrm{H})$; EIMS $m / z(\%): 137.1(53)\left[\mathrm{M}-\mathrm{C}_{8} \mathrm{H}_{9}\right]^{+}, 224.1$ (2) $\left[\mathrm{M}-\mathrm{H}_{2} \mathrm{O}\right]^{+}$, $242.1(1)[\mathrm{M}]^{+\cdot}$.

6,6-Dimethyl-2-phenylhept-4-yn-3-ol (Table 2, entry 4): The reaction was carried out under a dry nitrogen atmosphere by using standard Schlenk techniques. The solution of 3,3dimethyl-1-butyne $(0.62 \mathrm{~mL}, 5 \mathrm{mmol})$ in dry THF $(10 \mathrm{~mL})$ was cooled to $-78{ }^{\circ} \mathrm{C}$. $n$-BuLi (1.6 M in hexane, $3.5 \mathrm{~mL}, 5.6 \mathrm{mmol}$ ) was added dropwise through a septum by syringe. The reaction mixture was allowed to warm to $\mathrm{rt}$ before the solution of 2-propionaldehyde $(0.68 \mathrm{~mL}, 5 \mathrm{mmol})$ in dry THF $(5 \mathrm{~mL})$ was added dropwise through a septum by syringe. This solution was stirred for $4.5 \mathrm{~h}$. The reaction was stopped by the addition of $\mathrm{H}_{2} \mathrm{O}(10 \mathrm{~mL})$. The aqueous phase was extracted with diethyl ether $(3 \times 15 \mathrm{~mL})$, and the combined organic layers were dried with $\mathrm{MgSO}_{4}$. The solvent was removed with a rotary evaporator. The crude product was purified by flash chromatography (petroleum ether/ethyl acetate $4: 1, R_{\mathrm{f}} 0.42$; staining with vanillin solution gave a blue spot). 6,6-dimethyl-2-phenylhept4-yn-3-ol was isolated as a colorless oil in $46 \%$ yield $(0.50 \mathrm{~g}$, $2.3 \mathrm{mmol}) .{ }^{1} \mathrm{H}$ NMR (300 MHz, $\left.\mathrm{CDCl}_{3}\right) \delta 7.40-7.19(\mathrm{~m}, 5 \mathrm{H})$, $4.44(\mathrm{dd}, J=7.4,5.4 \mathrm{~Hz}, 1 \mathrm{H}), 3.03(\mathrm{dd}, J=7.1,5.4 \mathrm{~Hz}, 1 \mathrm{H})$, $1.67(\mathrm{~d}, J=5.4 \mathrm{~Hz}, 1 \mathrm{H}), 1.64$ (d, $J=7.4 \mathrm{~Hz}, 1 \mathrm{H}), 1.39$ (d, $J=$ $7.1 \mathrm{~Hz}, 3 \mathrm{H}), 1.17$ (s, 9H); ${ }^{13} \mathrm{C} \mathrm{NMR}\left(75 \mathrm{MHz}, \mathrm{CDCl}_{3}\right) \delta 141.9$, 128.8, 128.2, 127.0, 95.5, 78.1, 67.8, 67.5, 55.0, 46.1, 31.0, 30.0, 16.3; EIMS m/z (\%): $57.1(36)\left[\mathrm{C}_{4} \mathrm{H}_{9}\right]^{+}, 99.1(100), 105.1$ (20) $\left[\mathrm{C}_{8} \mathrm{H}_{10}\right]^{+}, 216.2(7)[\mathrm{M}]^{+\cdot}$.

\section{Supporting Information}

\section{Supporting Information File 1}

Spectroscopic data for the synthesis of some alcohols. Quantitative mass efficiency analysis of four alternative alcohol reduction reactions.

[http://www.beilstein-journals.org/bjoc/content/ supplementary/1860-5397-8-36-S1.pdf] 


\section{Acknowledgements}

We thank the Fachagentur Nachwachsende Rohstoffe for financial support. JH thanks the state of Bavaria for a $\mathrm{PhD}$ fellowship.

\section{References}

1. Larock, R. C., Ed. Comprehensive organic transformations: a guide to functional group preparations, 2nd ed.; Wiley-VCH: New York, 1999; pp 44-49.

2. McCombie, S. W. In Comprehensive Organic Synthesis; Trost, B. M.; Fleming, I., Eds.; Pergamon Press: Oxford, U.K., 1991; Vol. 8, pp 811-833. doi:10.1016/B978-0-08-052349-1.00247-X

3. Zard, S. Z. Xanthates and Related Derivatives as Radical Precursors. In Radicals in Organic Synthesis; Renaud, P.; Sibi, M. P., Eds.; Wiley-VCH: Weinheim, Germany, 2001; Vol. 1, pp 90-108. doi:10.1002/9783527618293.ch6

4. ten Dam, J.; Hanefeld, U. ChemSusChem 2011, 4, 1017-1034. doi:10.1002/cssc.201100162

5. Diéguez, H. R.; López, A.; Domingo, V.; Arteaga, J. F.; Dobado, J. A.; Herrador, M. M.; Quílez del Moral, J. F.; Barrero, A. F. J. Am. Chem. Soc. 2010, 132, 254-259. doi:10.1021/ja906083c

6. Ledon, H.; Tkatchenko, I.; Young, D. Tetrahedron Lett. 1979, 20 , 173-176. doi:10.1016/S0040-4039(01)85916-5

7. McMurry, J. E.; Silvestri, M. G.; Fleming, M. P.; Hoz, T.; Grayston, M. W. J. Org. Chem. 1978, 43, 3249-3255. doi:10.1021/jo00411a001

8. Sato, F.; Tomuro, Y.; Ishikawa, H.; Oikawa, T.; Sato, M. Chem. Lett. 1980, 9, 103-106. doi:10.1246/cl.1980.103

9. Corey, E. J.; Achiwa, K. J. Org. Chem. 1969, 34, 3667-3668. doi:10.1021/jo01263a114

10. Crevier, T. J.; Mayer, J. M. J. Am. Chem. Soc. 1997, 119, 8485-8491. doi:10.1021/ja970929s

11. Lee, J.-T.; Alper, H. Tetrahedron Lett. 1990, 31, 4101-4104. doi:10.1016/S0040-4039(00)97553-1

12. Spiegel, D. A.; Wiberg, K. B.; Schacherer, L. N.; Medeiros, M. R.; Wood, J. L. J. Am. Chem. Soc. 2005, 127, 12513-12515. doi:10.1021/ja052185I

13. Zhang, L.; Koreeda, M. J. Am. Chem. Soc. 2004, 126, 13190-13191. doi:10.1021/ja0462777

14. Barton, D. H. R.; McCombie, S. W. J. Chem. Soc., Perkin Trans. 1 1975, 1574-1585. doi:10.1039/p19750001574

15. Barton, D. H. R.; Jang, D. O.; Jaszberenyi, J. C. Synlett 1991, 435-438. doi:10.1055/s-1991-20755

16. Barton, D. H. R.; Jang, D. O.; Jaszberenyi, J. C. J. Org. Chem. 1993 , 58, 6838-6842. doi:10.1021/jo00076a054

17. Barton, D. H. R.; Motherwell, W. B.; Stange, A. Synthesis 1981, 743-745. doi:10.1055/s-1981-29587

18. Zard, S. Z. Angew. Chem., Int. Ed. Engl. 1997, 36, 672-685. doi:10.1002/anie.199706721

19. Appel, K. E. Drug. Metab. Rev. 2004, 36, 763-786. doi:10.1081/DMR-200033490

20. Boyer, I. J. Toxicology 1989, 55, 253-298. doi:10.1016/0300-483X(89)90018-8

21. Dopp, E.; Hartmann, L. M.; Florea, A.-M.; Rettenmeier, A. W.; Hirner, A. V. Crit. Rev. Toxicol. 2004, 34, 301-333. doi:10.1080/10408440490270160

22. Aloy, J.; Rabaut, C. Bull. Soc. Chim. Fr. 1911, 9, 762-764.
23. Aramini, A.; Sablone, M. R.; Bianchini, G.; Amore, A.; Fanì, M. Perrone, P.; Dolce, A.; Allegretti, M. Tetrahedron 2009, 65, 2015-2021. doi:10.1016/j.tet.2009.01.005

24. Dozeman, G. J.; Fiore, P. J.; Puls, T. P.; Walker, J. C. Org. Process Res. Dev. 1997, 1, 137-148. doi:10.1021/op9600419

25. Gordon, P. E.; Fry, A. J. Tetrahedron Lett. 2001, 42, 831-833. doi:10.1016/S0040-4039(00)02159-6

26. Harvey, R. G.; Leyba, C.; Konieczny, M.; Fu, P. P.; Sukumaran, K. B. J. Org. Chem. 1978, 43, 3423-3425. doi:10.1021/jo00411a048

27. Hicks, L. D.; Han, J. K.; Fry, A. J. Tetrahedron Lett. 2000, 41, 7817-7820. doi:10.1016/S0040-4039(00)01359-9

28. Marvel, C. S.; Hager, F. D.; Caudle, E. C. Org. Synth. 1923, 3, 45.

29. Miescher, K.; Billeter, J. R. Helv. Chim. Acta 1939, 22, 601-610. doi:10.1002/hlca.19390220174

30. Platt, K. L.; Oesch, F. J. Org. Chem. 1981, 46, 2601-2603. doi:10.1021/jo00325a041

31. Shaw, K. N. F.; Armstrong, M. D.; McMillan, A. J. Org. Chem. 1956, 21, 1149-1151. doi:10.1021/jo01116a023

32. Sugita, S.-I.; Toda, S.; Yoshiyasu, T.; Teraji, T. Mol. Cryst. Liq. Cryst. 1993, 237, 399-406. doi:10.1080/10587259308030152

33. Czaplicki, S.; Kostanecki, S. T. V.; Lampe, V. Ber. Dtsch. Chem. Ges. 1909, 42, 827-838. doi:10.1002/cber.190904201133

34. Milne, J. E.; Storz, T.; Colyer, J. T.; Thiel, O. R.; Dilmeghani Seran, M.; Larsen, R. D.; Murry, J. A. J. Org. Chem. 2011, 76, 9519-9524. doi:10.1021/j02018087

35. Wu, G. G.; Chen, F. X.; LaFrance, D.; Liu, Z.; Greene, S. G.; Wong, Y.-S.; Xie, J. Org. Lett. 2011, 13, 5220-5223. doi:10.1021/ol102174w

36. Deno, N. C.; Friedman, N.; Hodge, J. D.; MacKay, F. P.; Saines, G. J. Am. Chem. Soc. 1962, 84, 4713-4715. doi:10.1021/ja00883a019

37. Gordon, P. E.; Fry, A. J.; Hicks, L. D. ARKIVOC 2005, vi, 393-400.

38. Ogg, R. A., Jr. J. Am. Chem. Soc. 1934, 56, 526-536. doi:10.1021/ja01318a007

39. Eissen, M.; Metzger, J. O. Chem.-Eur. J. 2002, 8, 3580-3585. doi:10.1002/1521-3765(20020816)8:16<3580::AID-CHEM3580>3.0.C O;2-J

40. Takahashi, M.; McLaughlin, M.; Micalizio, G. C. Angew. Chem., Int. Ed. 2009, 48, 3648-3652. doi:10.1002/anie.200900236

41. Zhou, C.; Wang, Z. Synthesis 2005, 1649-1655. doi:10.1055/s-2005-865293

\section{License and Terms}

This is an Open Access article under the terms of the Creative Commons Attribution License (http://creativecommons.org/licenses/by/2.0), which permits unrestricted use, distribution, and reproduction in any medium, provided the original work is properly cited.

The license is subject to the Beilstein Journal of Organic Chemistry terms and conditions: (http://www.beilstein-journals.org/bjoc)

The definitive version of this article is the electronic one which can be found at: doi:10.3762/bjoc. 8.36 